MINERALOGIA, 44, No 3-4: 115-124 (2013)

DOI: 10.2478/mipo-2013-0008

www.Mineralogia.pl

MineRALOgICAL Society of Poland

POLSKIE TOWARZYSTWO MINERALOGICZNE

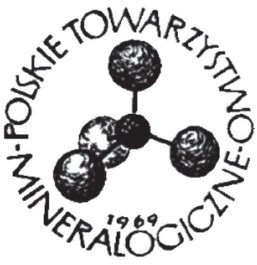

Review paper

\title{
Alkaline rocks of the Ukrainian Shield: Some mineralogical, petrological and geochemical features
}

\author{
Aleksandr N. Ponomarenko ${ }^{1 *}$, Stepan G. Kryvdik ${ }^{2}$, Aleksandr V. Grinchenko ${ }^{3}$ \\ ${ }^{1}$ Institute of Geochemistry, Mineralogy and Ore Formation M.P.Semenenko, NAS of Ukraine \\ Director of Institute, Corresponding member NAS of Ukraine, 34, Palladina av., Kiev-142, 03680 Ukraine; \\ e-mail:pan@igmof.gov.ua \\ ${ }^{2}$ Institute of Geochemistry, Mineralogy and Ore Formation M.P.Semenenko, NAS of Ukraine \\ Senior Research Scientist, Candidate of science, 34, Palladina av., Kiev-142, 03680 Ukraine; \\ e-mail:kryvdik@ukr.net \\ ${ }^{3}$ Taras Shevchenko National University of Kyiv, Geological faculty Docent, Candidate of science, 90 Vasyl'kivska \\ str., Kyiv 03022 Ukraine; e-mail: alexgrin@univ.kiev.ua \\ * Corresponding author
}

Received: December 30, 2010

Received in revised form: 28 November, 2013

Accepted: March 16, 2014

Available online: July 20, 2014

Abstract. The Ukrainian Shield (USh) is a typical province of Proterozoic alkaline magmatism where about 50 massifs and occurrences of alkaline rocks and carbonatites have been found. In spite of the wide distribution of Devonian basaltic- and alkaline magmatic rocks in the Dnieper-Donetsk depression adjacent to the USh, and in a marginal zone of the USh adjacent to folded Donbass, only alkaline rocks of Proterozoic age (1.8-2.1 Ga) that have been identified in the central interior of the USh. Some discrete bodies of $2.8 \mathrm{Ga}$ subalkaline rocks also occur in Bogdanivka massif (Azov area). Occurrences of both Proterozoic (prevailing) and Phanerozoic (Devonian) alkaline rocks and kimberlites are only found in the eastern part of the USh (Azov area). Kimberlites in the central part of the Ukrainian Shield (Kirovograd region) are also of Proterozoic age (ca $1.8 \mathrm{Ga}$ ). It is this predominance of Precambrian rocks that makes the USh so different from other alkaline provinces where Phanerozoic alkaline rocks and kimberlites commonly prevail over Precambrian rocks. The lack of Phanerozoic alkaline magmatism on USh is poorly understood.

Two main complexes of alkaline rocks - alkaline-ultrabasic (carbonatitic) and gabbro- syenitic - are distinguished in the USh. There are also rare occurrences of rock types such as alkaline- and alkaline-feldspar granites that may represent one separate alkaline-granite complex. Alkaline rocks present in the Eastern (Azov) province and in the Western province display essentially different geochemical character. Those of the Eastern province show characteristics typical of alkaline-ultrabasic rocks (e.g. high contents of incompatible rare elements 
such as $\mathrm{Nb}$, REE, $\mathrm{Zr}$, Y, Sr, whereas those in the Western province are characterized by low contents of $\mathrm{Nb}$ and $\mathrm{Zr}$, and REE in some cases. This fact is interpreted as reflecting different geodynamic conditions of their origin. The Eastern rocks were formed in rift settings, the Western rocks in crustal compressional settings (collision, subduction). Various mineral deposits of phosphorus (apatite), niobium, REE, yttrium and zirconium, including unusually rich ores of REE, Y and $\mathrm{Zr}$ (Azov and Yastrybetsky) are associated with the alkaline rocks and carbonatites of the USh.

Key-words: Ukrainian Shield, alkaline magmatism, Proterozoic, Devonian kimberlites

\section{Introduction}

The Ukrainian Shield (USh) consists of both Archean- and Proterozoic domains. Some researchers believe that these domains are fragments of a single craton (Shcherbak et al. 2000; Kirilyuk et al. 2002; Shcherbak et al. 2005, 2008), in line with the view that plate tectonic processes were of limited importance in Precambrian times (Stern 2007; Hamilton 2011). Others, favoring the plate tectonic paradigm, consider the Ukrainian shield to be a Proterozoic collage of discrete terranes (Glevassky et al. 2002; Claesson et al. 2006). In the geological history, the earliest manifestation of intensive alkaline magmatism is essentially confined to the Proterozoic and most occurrences are related to the Mesozoic and Cenozoic Eras (Kogarko 1998; Downes 2012). These facts are additionally used to substantiate the thesis that plate-tectonic mechanisms operated from the ArcheanProterozoic boundary at least (Kogarko et al. 2001).

On the USh, more than 50 massifs and smaller occurrences of alkaline rocks have been found (Kogarko et al. 1995). However, the majority of these alkaline rocks belong to the Proterozoic epoch $(1.7-2.1 \mathrm{Ga})$ unlike other regions of the world where Phanerozoic alkaline rocks prevail. Alkaline rocks of Devonian age are also widely distributed in areas adjacent to the Ukrainian Shield - the Dnieper-Donetsk depression and junction zone between the USh and the folded Donbass zone. Some Devonian alkaline rocks and kimberlites that occur in the Azov area, a marginal province of the USh, do so only in association with Proterozoic alkaline complexes. In the central internal part of the USh, only Proterozoic alkaline rocks have been found up to now. Even kimberlites of the Kirovograd geoblock in this central part show a Proterozoic age of ca $1.8 \mathrm{Ga}$. The paucity of Phanerozoic alkaline magmatism within the USh remains an unresolved question.

At present, two main complexes of alkaline rocks, alkaline-ultrabasic (carbonatitic) and gabbro-syenitic, are distinguished within the territory of Ukraine (Kryvdik et al. 1990). In addition to these, there are alkaline (with aegirine and riebeckite)- and alkaline-feldspar biotitic granites of Proterozoic age and some dikes (grorudites, i.e. vein analogues of comendites and pantellerites; Brögger (1890)) of Devonian age. Two main stages of Precambrian alkaline activity at 2.0-2.1 and 1.7-1.8 Ga have been distinguished within the Ukrainian Shield (Table 1). Complexes of predominantly alkaline-ultrabasic (carbonatitic) composition are associated with the first stage and gabbro-syenitic complexes with the second. Though some separate occurrences of subalkaline syenites dated at ca 2.0 and $2.8 \mathrm{Ga}$ occur in the Starobogdanivka complex of the Azov area (Shcherbak et al. 2005), these potentially oldest examples of the alkaline rocks are still insufficiently studied to be discussed here. Two main provinces of alkaline magmatism, Eastern Azov and Western, 
occur within the Ukrainian Shield (Fig. 1). Some occurrences of alkaline- and subalkaline rocks are associated with Korosten- and Korsun-Novomyrgorod anorthosite-granite rapakivi plutons. These involve subalkaline (two-feldspar)-, alkaline-feldspar- and alkaline (with aegirine and riebeckite) syenites which commonly occur as veins and small massifs either inside or on the margins of anorthosite-granite rapakivi plutons (Fig. 1).

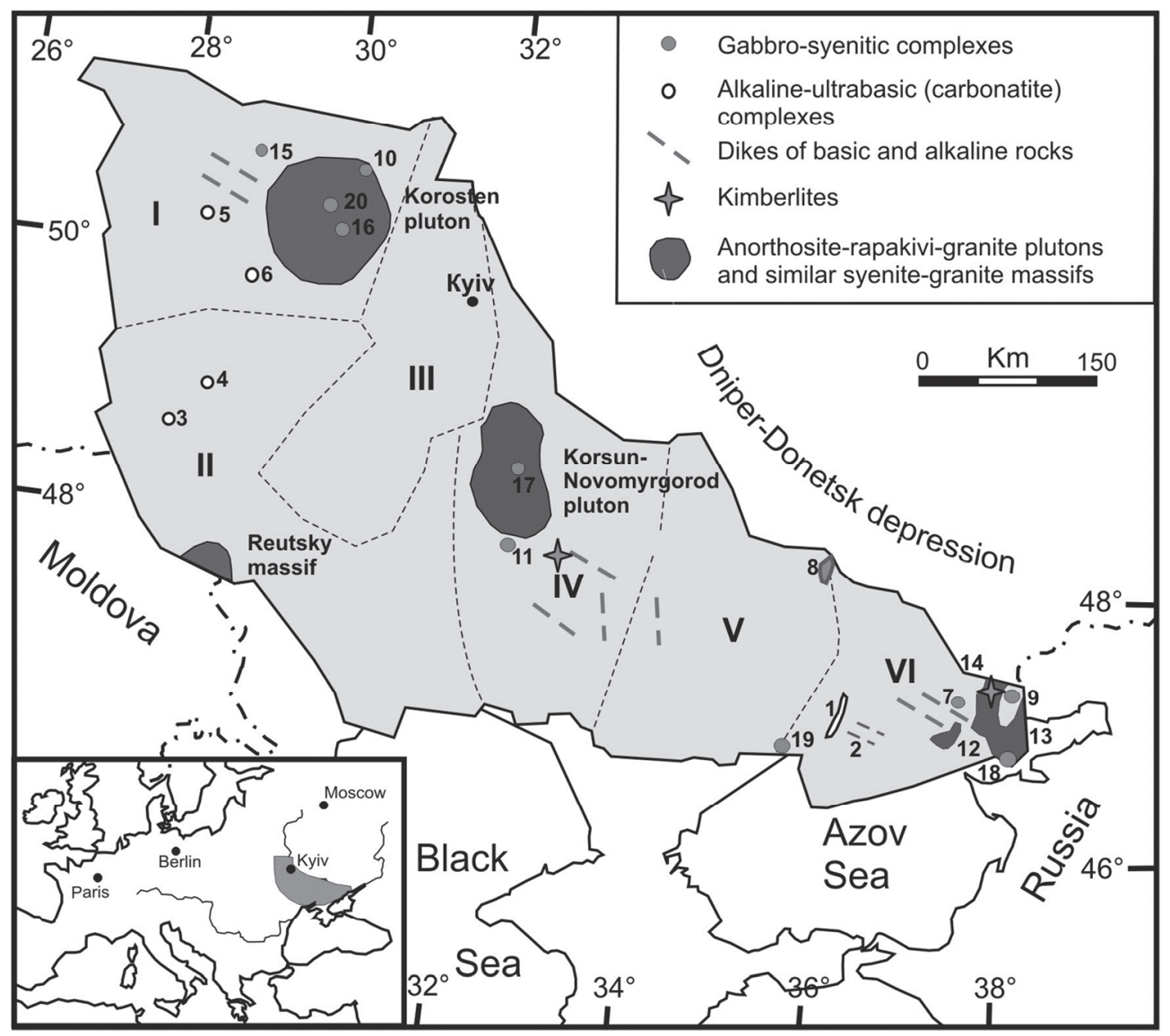

Fig. 1. Massifs and occurrences of carbonatites, alkaline and subalkaline rocks of the Ukrainian Shield. Geological blocks (provinces) of the Ukrainian Shield: I - Northwest; II - Dnistr-Bug; III Ros-Tikych; IV - Ingul; V - Middle-Dniper; VI - Azov.

Alkaline-ultrabasic (carbonatite) complexes: 1 - Chernigivka, 2 - dikes of metajakupirangites, 3 Proskurivka, 4 - Antonivka, 5 - Gorodnitsa intrusive bodies, 6 - fenites of Beresova Gat'.

Gabbro-syenitic complexes: 7 - Octyabrsky, 8 - Mala Tersa, 9 - Pokrovo-Kyriyevo, 10 - Davydky, 11 - Velyka Vyska, 12 - South Kalchyk, 13 - Elanchyk, 14 - Kalmius, 15 - Yastrubetsky, 16, 17 aegerinic syenites of Korosten and Korsun-Novomyrgorod plutons, 18 - Prymorye, 19 - Melitopol, 20 - Stremygorod apatite-ilmenite deposit.

In some early attempts to classify the rocks of the complexes, it did not prove possible to always relate particular occurrences of alkaline rocks to given associations/complexes in the USh as named above. However, it was recognized that particular massifs or occurrences 
of alkaline rocks related to the same complex often display characteristic specific- and regional compositional features. Some occurrences of the same alkaline-ultrabasic rock complexes of the Eastern Azov- and Western provinces show contrasting contents of Nb, $\mathrm{Zr}$ and REE (Kryvdik et al. 1990). These geochemical differences might relate to differing geodynamic settings of formation.

Ore occurrences and mineral deposits of both typical- (apatite, niobium, rare-earth elements) and peculiar types (enriched in rare earth elements, Y and Zr. Azov and Yastrybetsky deposits) are associated with alkaline rocks and carbonatites of the USh (Kryvdik et al. 2002; Kryvdik 2002). Alkaline rocks of certain complexes/associations that are distinguished by their accessory minerals are considered below.

\section{Alkaline-ultrabasic (carbonatitic) complexes}

The alkaline-ultrabasic complexes are usually mentioned in the English literature as being carbonatitic. However, as the majority of them are not yet known to contain carbonatites, we prefer to call them alkaline-ultrabasic complexes. It is assumed that most of the complexes are potentially carbonatite-bearing. They were initially discovered in the USh (since 1980s) in the eastern province, e.g. in the Azov area (Chernigivka massif and some other small occurrences) and, recently, they were also discovered in the Western province of the shield (Fig 1). Among the latter, the alkaline-ultrabasic massifs of Proskurivka, Antonivka, Gorodnitsa, Glumcha, Boliarka are notable (Tsymbal et al. 1997; Kryvdik et al. 2003; Tsymbal et al. 2008).

Major components of the alkaline-ultrabasic complexes of the USh include alkaline pyroxenite-jakupirangite, ijolite-melteigite, nephelinite and alkaline syenite in addition to carbonatite (Chernigivka massif). Varying proportions of each rock type characterize the different massifs. In common with alkaline-ultrabasic massifs worldwide, the USc massifs are surrounded by aureoles of intensely fenitized country rock. Alkaline metasomatites, widely distributed in the eastern part of Azov area, and which are not associated with outcrops of alkaline rock, are assumed to be fenites related to unexposed carbonatitic complexes.

The USh massifs have not been thoroughly investigated geochronologically as yet. The carbonatites of the most completely studied Chernigivka Massif (Azov area) have been dated at $1804 \pm 6.7 \mathrm{Ma}$ by the U-Pb method (Zagnitko et al. 1993). Similar ages (1.9$2.0 \mathrm{Ga}$ ) have been obtained from baddeleyite, monazite, sphene, micas and amphiboles from various rocks in this complex. The alkaline-ultrabasic rock complexes of the Western part of the USh are characterized by unusually low zircon contents, inhibiting geochronological study. In contrast, zircon is a typical mineral in most rocks from the alkaline-ultrabasic massifs of the Azov areas. Rocks from the Proskurivka and Antonivka massifs there give very divergent isotopic ages, i.e. $2.0 \mathrm{Ga}$ obtained using the zircon $\mathrm{Pb}-\mathrm{Pb}$ method and $\mathrm{K}-\mathrm{Ar}$ ages of 1.2-1.6 Ga on amphiboles and biotites. Rocks from the Gorodnitsa massif give quite convergent ages for zircon and amphibole (2.0 Ma) (Kryvdik et al. 2000; Kryvdik et al. 2002; Kryvdik et al. 2006b).

All of the studied massifs can be classified in terms of their level of erosion at current Earth's surface. Massifs such as Gorodnitsa, Glumcha and Boliarka reflect a hypabyssal level of intrusion exposed by a limited degree of erosion, whereas Proskurivka and 
Antonivka represent deeply eroded $(<10 \mathrm{~km})$ massifs. To explain the observed divergences in age values obtained from different minerals, Dubyna et al. (2006) and Kryvdik et al. (2006b) assumed that deeply-eroded alkaline intrusions had, for a long time (from the Riphean) in abyssal settings, been subject to temperatures $>300^{\circ} \mathrm{C}$. As a result amphiboles and biotites lost radiogenic argon and only much later nearer the surface did their K-Ar systems begin to record the passage of time (Dubina et al. 2006).

By taking into account the many occurrences of fenites in Azov area, it is possible to conclude that there are likely to be many more Paleoproterozoic carbonatitic (alkalineultrabasic) complexes within the USh than in comparable regions elsewhere. However, as mentioned above, Phanerozoic carbonatitic complexes prevail elsewhere. Older (2.4$3.0 \mathrm{Ga}$ ) complexes coeval in age with the Ukrainian carbonatitic occurrences are encountered rather rarely though possible examples of the latter are the complexes of Tupertalik in Greenland, Siilinjarvi in Finland and Grays Bay in Canada (Blichert-Toft et al. 1996; Downes et al. 2012).

At present, only one occurrence of young Devonian effusive carbonatites, confined to the junction zone between USh and folded Donbass, is known in the Ukraine (Shramenko et al. 1992). These are probably carbonatites of similar age to those found within the Dnieper-Donetsk and Prypiat depressions where some complexes of alkaline-ultrabasic rocks (nephelinites, melteigites, alkaline and nepheline pyroxenites, phonolits) also occur (Lyashkevich et al. 1977).

\section{Gabbro-syenitic complexes}

These complexes occur mainly in the Azov area (Fig. 1). Most of them show a close association with anorthosite-granite rapakivi plutons. It is widely considered that they were emplaced at relatively shallow depths compared to the alkaline-ultrabasic varieties and that they derived from melts of different alkalinity. Alkaline basalts were primary for such complexes as Octyabrsky and Mala Tersa the formation of which was completed by nepheline syenites or phonolits, including their agpaitic varieties. Hypabyssal Devonian complexes that are possibly genetically associated with alkaline basalts (Pokrovo-Kyryevo, Zirka, Mariupol, Khomutovo, Prymorsky, etc.) also occur in the Azov area.

Gabbro (usually subalkaline), pyroxenites, less common peridotites, and alkaline- and nepheline syenites are among the main rocks of these complexes. Other types are associated with anorthosite-granite rapakivi plutons (Korosten, Korsun-Novomyrgorod) and represented by syenites, quartz syenites or subalkaline- and alkaline granites. It is necessary to emphasize that the anorthosite-granite rapakivi plutons of the USh are characterized by an abundance of syenites located either inside the plutons or which form separate small massifs among country granite-gneisses at their margins. Based on this fact, Kryvdik et al. (1990) proposed that the anorthosite-granite rapakivi plutons of the USh show a syenitic trend of differentiation in parallel with a granitic trend. The South Kalchyk gabbro-syenitic massif of the Azov area is considered to be essentially a syenitic analogue of these plutons (Kryvdik et al. 1990; Karmazin 1970). These syenites contain two unusual rare-earth ore deposits rich in Y and Zr, i.e. the Azov- and Yastrubetsky deposits (Strekozov et al. 1998; Kryvdik et al. 2000; Melnikov et al. 2000). 
At present, among the geochronologically studied gabbro-syenitic massifs are those of Octyabrsky, South Kalchyk and Yastrubetsky (Alkaline rocks: Petrology, mineralogy and geochemistry, 2010). All rock types in these complexes (gabbroides, nepheline and alkaline syenites, and their ores rich in zircon) give U-Pb ages close to $1.8 \mathrm{Ga}$. The ore-bearing syenites of Yastrubetsky massif yield younger ages $(1.77 \mathrm{Ga})$. These datings are essentially the same as those obtained for the rapakivi granites and gabbroides of the Korosten and Korsun-Novomyrgorod plutons (Verchogliad 1995; Scherbak et al. 2008). It should be noted that the anorthosite-granite rapakivi plutons of USh are also the most ancient in comparison with other similar plutons of the East European craton. The ages of similar plutons on the Baltic Shield, for example, range from 1.5-1.7 Ga and similar rocks in Poland (Suwalki Anorthosite Massif) have been dated at $1.55 \mathrm{Ga}$.

In terms of its age, the Mala Tersa complex (Kryvdik et al. 1990) located in the Orykhiv-Pavlograd suture zone which consists of alkaline- and nepheline syenites with subordinate subalkaline gabbros is a little different; this complex yields two ages of 1.86 and $2.05 \mathrm{Ga}$ (Zagnitko et al. 1993; Table 1). The assumption has been made that the Mala Tersa massif comprises complexes of two different ages, an earlier carbonatitic complex similar to Chernigivka and a later gabbro-syenitic one. It should be noted that some veins of carbonatites and of carbonatite-similar rocks have also been found in the Mala Tersa massif (Shramenko et al. 1992). Alkaline metasomatites similar to the fenites of the carbonatitic complexes are also developed in the western contact of this massif.

Available dates $(1720 \pm 30 \mathrm{Ma}$ on zircon) for the aegerinic syenites from the internal part of the Korosten pluton (Table 1) practically coincide with those for the rapakivi granites. Similar aegerine syenites are also found in the Korsun-Novomyrgorod pluton (Kryvdik et al. 1990) though they are undated up to now. These syenites are different from the rocks that form discrete mostly syenitic massifs, e.g. South Kalchyk with the Azov deposit, Yastrubetsky and Velyka Vyska. Characteristic rock-forming dark-coloured minerals are represented by fayalite, hedenbergite, hastingsite and annite. Only in the most differentiated Yastrubetsky massif are there riebeckite- and aegerine-syenite varieties. These syenites are commonly enriched in $\mathrm{Zr}$, REE, $\mathrm{Y}$ and, to a degree, $\mathrm{Nb}$ and some deposits of rich Zr, REE, Y ores (Azov and Yastrubetsky) are associated with them.

Other alkaline rocks in Azov have not yet been adequately studied geochronologically. Based on field observation, a Devonian age has been proposed for some of them (PokrovoKyryevo, Prymorsky, Mariupol, Zirka) (Gonshakova 1973; Kryvdik et al. 2006b). Younger Triassic and Jurassic ages have also been proposed for some alkaline- and subalkaline rocks of the Azov area though there is, as yet, no convincing supporting evidence. For a long time, for example, grorudites of the eastern part of the Azov area have been deemed to be a Triassic-Jurassic complex on the basis of K-Ar dating. However, the oldest K-Ar dating (400 Ma) on riebeckite from these rocks testifies to their Devonian age (Kryvdik et al. 1990). Grorudites from different dikes appear, on chemical and mineralogical grounds, to be analogues of pantellerites and komendites (Kryvdik et al. 1990).

Therefore, we would like to note that many alkaline complexes in the USh merit additional geochronological and geochemical investigation. Included are dikes of subalkaline and alkaline rocks of the Azov area, and of the Central (Kirovograd region) and Northwestern provinces of the USh. Many other occurrences of alkaline metasomatites in the eastern part of Azov area are also poorly dated. 
Brief description of the main massifs and occurrences of alkaline rocks the Ukrainian Shield.

\begin{tabular}{llll}
\hline $\begin{array}{l}\text { Massif, } \\
\text { occurrence }\end{array}$ & $\begin{array}{l}\text { Rocks (listed in order of } \\
\text { established or supposed } \\
\text { sequence of their } \\
\text { formation) }\end{array}$ & $\begin{array}{l}\text { Features of geological } \\
\text { structure }\end{array}$ & $\begin{array}{l}\text { Age, in Ma } \\
\left(\text { on } \mathrm{K}-\mathrm{Ar}^{*} \text { and U- }\right. \\
\mathrm{Pb} * * \text { methods })\end{array}$ \\
\end{tabular}

Alkaline-ultrabasic complex

\begin{tabular}{|c|c|c|c|}
\hline $\begin{array}{l}\text { Chernigivka massif } \\
\text { (Western Azov area) }\end{array}$ & $\begin{array}{l}\text { Alkaline pyroxenites, } \\
\text { ijolite - melteigites, } \\
\text { canadites, alkaline } \\
\text { syenites, tveitosites, } \\
\text { carbonatites, fenites }\end{array}$ & $\begin{array}{l}\text { Linearly-elongated } \\
\text { carbonatitic complex }\end{array}$ & $1820 *-2190 * *$ \\
\hline $\begin{array}{l}\text { Belt of dikes of alkaline } \\
\text { metaultrabasic rocks in } \\
\text { the Western Azov area }\end{array}$ & $\begin{array}{l}\text { Hornblendites, } \\
\text { (metajakupirangites), more } \\
\text { rare microcline- } \\
\text { hornblendites and apatite- } \\
\text { actinolite rocks }\end{array}$ & $\begin{array}{l}\text { Dikes, more often } \\
\text { northwest }\left(320^{\circ}\right) \text {, and } \\
\text { more rare submeridional } \\
\text { strike; thickness of dikes } \\
\text { from } 20-50 \mathrm{~cm} \text { to several } \\
\text { metres }\end{array}$ & $1950 *$ \\
\hline $\begin{array}{l}\text { Veins of carbonatites: } \\
\text { Hlebodarovka open pit } \\
\text { (East Azov area) }\end{array}$ & $\begin{array}{l}\text { Calcite carbonatites with } \\
\text { aegirine, alkaline } \\
\text { amphibole and accessory } \\
\text { pyrochlore and monazite }\end{array}$ & $\begin{array}{l}\text { Low-thickness (to } 40 \mathrm{~cm} \text { ) } \\
\text { veins of carbonatites; } \\
\text { intensive exocontact } \\
\text { fenitization of host } \\
\text { enderbite-charnokites }\end{array}$ & $1850 *$ \\
\hline $\begin{array}{l}\text { Proskurivka massif } \\
\text { (Dniester region) }\end{array}$ & $\begin{array}{l}\text { Ijolite - melteigites, } \\
\text { feldspar ijolites, } \\
\text { nephelinic syenites, } \\
\text { fenites, tveitosites }\end{array}$ & $\begin{array}{l}\text { Slightly elongated massif } \\
\text { with close to isometric } \\
\text { shape; intensive } \\
\text { fenitization of host } \\
\text { granitoids }\end{array}$ & $2100 \pm 40 * *$ \\
\hline $\begin{array}{l}\text { Fenites of Berezova } \\
\text { Gat (Northwest part the } \\
\text { Ukrainian Shield) }\end{array}$ & $\begin{array}{l}\text { Fenites, aegerinic albitites, } \\
\text { more rare microclinites } \\
\text { and zeolitized fenites }\end{array}$ & $\begin{array}{l}\text { Steeply dipping body of } \\
\text { northwest strike with } \\
\text { variable thickness (from } \\
40-60 \text { to } 150 \mathrm{~m} \text { ) }\end{array}$ & $1800 * *-2130 * *$ \\
\hline $\begin{array}{l}\text { Gorodnitsa occurrence } \\
\text { (northwest part of the } \\
\text { Ukrainian Shield) }\end{array}$ & $\begin{array}{l}\text { Olivine containing and } \\
\text { olivinic ijolite - melteigites } \\
\text { and jakupirangites }\end{array}$ & $\begin{array}{l}\text { Body with thickness of } \\
\text { about } 100 \mathrm{~m}\end{array}$ & $2000 * *$ \\
\hline
\end{tabular}


Gabbro-syenitic complex

Massifs with nepheline-syenitic differentiates as late stage of their formation

\begin{tabular}{|c|c|c|c|}
\hline $\begin{array}{l}\text { Octyabrsky massif } \\
\text { (Azov area) }\end{array}$ & $\begin{array}{l}\text { The gabbro - pyroxenites, } \\
\text { peridotites, alkaline } \\
\text { syenites, foyaites, } \\
\text { mariupolites, agpaitic } \\
\text { (eudialytic) phonolites }\end{array}$ & $\begin{array}{l}\text { Massif close to oval } \\
\text { shape with elements of } \\
\text { ring structure }\end{array}$ & $1800 * *$ \\
\hline $\begin{array}{l}\text { Mala Tersa massif of } \\
\text { (Orekhiv-Pavlograd } \\
\text { suture zone }\end{array}$ & $\begin{array}{l}\text { Gabbro-diabases, alkaline } \\
\text { and nephelinic syenites } \\
\text { (foyaites), foyaite- } \\
\text { porphyries, fenites }\end{array}$ & $\begin{array}{l}\text { Concentrically zonal } \\
\text { massif with lopolithic } \\
\text { shape }\end{array}$ & $1800-2050 * *$ \\
\hline $\begin{array}{l}\text { Pokrovo-Kiriyevo massif } \\
\text { (zone of junction between } \\
\text { Azov area and Donbass) }\end{array}$ & $\begin{array}{l}\text { Gabbro, pyroxenites, } \\
\text { peridotites, dunites- } \\
\text { malignites and juvites }\end{array}$ & $\begin{array}{l}\text { Stock-like bodies of } \\
\text { intrusive rocks }\end{array}$ & $300-410^{*}$ \\
\hline
\end{tabular}

Massifs with syenitic, quartz-syenitic and granosyenitic differentiates as late stage of their formation

\begin{tabular}{|c|c|c|c|}
\hline $\begin{array}{l}\text { Davydky massif } \\
\text { (Northeast margin of } \\
\text { Korosten pluton, } \\
\text { Northwest part of the } \\
\text { Ukrainian Shield) }\end{array}$ & $\begin{array}{l}\text { Gabbro-diabases, troctolites, } \\
\text { magnetite gabbro, cumulates } \\
\text { of ultrabasic composition, } \\
\text { andesinites, syenites }\end{array}$ & $\begin{array}{l}\text { Rounded } \\
\text { concentrically-zonal } \\
\text { layered massif of } \\
\text { lopolith-likke shape }\end{array}$ & about $\sim 1,7 \mathrm{Ga}^{*}$ \\
\hline $\begin{array}{l}\text { Syenites of southern } \\
\text { margin of Korsun- } \\
\text { Novomyrgorod pluton }\end{array}$ & $\begin{array}{l}\text { Fayalite-hedenbergite } \\
\text { monzonites, monzosyenites } \\
\text { and syenites }\end{array}$ & $\begin{array}{l}\text { Small massifs, dikes } \\
\text { and bodies }\end{array}$ & $1780^{* *}$ \\
\hline $\begin{array}{l}\text { South Kalchyk massif, } \\
\text { Azov deposit }\end{array}$ & $\begin{array}{l}\text { Gabbro, magnetite gabbro } \\
\text { and peridotites, fayalite- } \\
\text { hedenbergite and hastingsite } \\
\text { syenites, granosyenites, } \\
\text { granites }\end{array}$ & Large massif $\left(330 \mathrm{~km}^{2}\right)$ & $1800 *$ \\
\hline $\begin{array}{l}\text { Yastrebetsky massif } \\
\text { (northwest part the USh) }\end{array}$ & $\begin{array}{l}\text { Biotite-hedenbergite, } \\
\text { hedenbergite-hastingsite, } \\
\text { hastingsite, riebeckitic and } \\
\text { aegerinic syenites, syenites } \\
\text { and granosyenites }\end{array}$ & $\begin{array}{l}\text { Oval layered massif } \\
\left(4 \mathrm{~km}^{2}\right) \text { with } \\
\text { supposedly lopolith- } \\
\text { like shape }\end{array}$ & $1770 * *$ \\
\hline Korosten pluton & $\begin{array}{l}\text { Aegerinic syenites and } \\
\text { quartz syenites, andradite- } \\
\text { aegerinic syenites }\end{array}$ & $\begin{array}{l}\text { Veins in rapakivi- } \\
\text { granites }\end{array}$ & $1720 \pm 30 * *$ \\
\hline
\end{tabular}

In summary, it is worth noting that the main age intervals of alkaline magmatism defined by geochronological investigations in the USh $(2.8 ; 2.1-2.0 ; 1.8-1.7 ; 0.4 \mathrm{Ga})$ do not coincide with the basic cycles of alkaline magmatism of the earth $(2.66 ; 1.86 ; 1.16 ; 0.52$; $0.36 ; 0.28$ and $0.12 \mathrm{Ga}$ ) which others (Balashov et al. 2006) are identified, though some ages are similar. This fact points, perhaps, to some peculiar feature (specialization) in the 
Ukrainian Shield. However, future geochronological investigations of these alkaline rocks will likely reveal other ages.

\section{Conclusions}

The Ukrainian Shield is a unique province of Proterozoic (1.7-2.1 Ga) alkaline magmatism. For a long time, this region was very passive with regard to Phanerozoic alkaline (and basalt trappean) magmatism. This particular history defines the region as different from other Precambrian shields and platforms. Paleozoic (Devonian) alkaline rocks are found, together with the Proterozoic rocks, only in the most eastern province (Azov area) of the Ukrainian Shield and on the junction between it and the adjacent folded Donbass.

Acknowledgements. This study was supported by the project of international cooperation between National Academy of Science of the Ukraine and the Russian Foundation for Basic Research (project No. 1-F/2010).

\section{References}

Alkaline rocks: Petrology, mineralogy and geochemistry. (2010). Programme. Abstracts. Excursion guide. Conference dedicated to the memory of J. A. Morozewicz, 19-21. September, 2010. Kyiv. Ukraine: Institute of geochemistry, mineralogy and ore formation M.P.Semenenko, NAS of Ukraine, 94.

Balashov, Yu A., \& Glaznev, V.N. (2006). Cycles of alkaline magmatism. Geochemistry, 3, 309-321 (in Russian).

Blichert-Toft, J., Amdt, N.T., \& Ludden, J.N. (1996). Precambrian alkaline magmatism. Lithos, 37, 97-111. DOI: 10.1016/0024-4937(95)00031-3.

Brögger, W.C. (1890). Die Mineralien der Syenitpegmatitgänge der südnorwegischen Augit- und Nephelinsyenite. Zeitschrift für Krystallographie, 16, 1-235, 1-663.

Claesson, S., Bibikova, E., Bogdanova, S., \& Skobelev V. (2006). Archalean terranes, paleoproterozoic reworking and accretion in the Ukrainian Shield, East European Craton. In: Gee, D.G., Stephensson, R.A. (Eds.), Europeran Lithosphere Dynamics, 32. Geological Society, London, Memoirs, 32, 645-654.

Downes, H., Wall, F., Demeny, A., \& Szabó, Cs. (2012). Continuing the carbonatite controversy. Preface. Mineralogical Magazine, 76(2), 255-257. DOI: 10.1180/minmag.2012.076.2.01.

Dubina, A.V., \& Kryvdik, S.G. (2006). Possible reasons of divergence of data of isotopic dating on U-Pb and K$\mathrm{Ar}$ methods of alkaline rocks of Dnister-Bug area of the Ukrainian Shield. Proceedings $-3^{\text {rd }}$ Russian Conference on Isotope Geochronology "Isotopic dating of processes of ore formation, magmatism, sedimentation and metamorphism“, 6-8 June 2006, Moscow, Russia: Institute of Geology of Ore Deposits, Petrography, Mineralogy and Geochemistry of Russian Academy of Sciences, 230-232 (in Russian).

Kirilyuk, V.P., Lysak, A.M., \& Velikanov, V.Ya. (2002). Basic features of early Precambrian tectonics of the Ukrainian Shield. Mineralogical Journal (Ukraine), 24(4), 39-46 (in English).

Glevassky, E.B., \& Glevasska, A.M. (2002). The Ukrainian Shield: Precambrian regional structure and paleogeodynamics. Mineralogical Journal (Ukraine), 24(4), 47-57 (in English).

Gonshakova, V.I. (1973). Basic-hyperbasic magmatism and mineralogy of southern part of the East-European platform (Platform stage of development). Moscow: Nedra, 294 (in Russian).

Hamilton, W.B. (2011). Plate tectonics began in Neoproterozoic time, and plumes from deep mantle have never operated. Lithos, 123, 1-20. DOI:10.1016/j.lithos.2010.12.007.

Karmazin, P.S. (1970). Azov batholite, its structural and age position. Geological Journal (Ukraine), 5, 137-143 (in Ukrainian).

Kogarko, L.N., Kononova, V.A., Orlova, M.P., \& Woolley, A.R. (1995). Alkaline rocks and carbonatites of the world. Part. 2: Former USSR. London: Chapman \& Hall. 226.

Kogarko, L.N. (1998). Alkaline magmatism in early history of the Earth. Petrology, 6(3), 251-258 (in Russian). 
Kogarko L.N, \& Chain V.E. (2001). Alkaline magmatism in history of the Earth: experience of geodynamic interpretation. Reports of Russian Academy of Science, 37(5), 688-679. (in Russian).

Kryvdik, S.G., \& Tkachuk, V.I. (1990). Petrology of alkaline rocks of the Ukrainian Shield. Kyiv: Naukova Dumka, 408 (in Russian).

Kryvdik, S.G., Zagnitko, V.N., \& Strekozov, S.N. (2000). Rare-metal syenites of the Ukrainian Shield: survey prospects of rich ores in zirconium and lanthanoides. Mineralogical Journal (Ukraine), 22(1), 62-72 (in Ukrainian).

Kryvdik, S.G., Melnikov, V.S., \& Zagnitko, V.M. (2002). Endogenic deposits of rare-metals in the Ukrainian Shield. Mineralogical Journal (Ukraine), 24 (2/3), 24-36.

Kryvdik, S.G. (2002). Rare-metal syenites of the Ukrainian Shield. Geochemistry, 7, 707-717 (in Russian).

Kryvdik, S.G., Tsymbal, S.N., \& Geiko, Yu.V. (2003). Proterozoic ultrabasic magmatism of the North-Western part of the Ukrainian Shield. Mineralogical Journal (Ukraine), 25(5/6), 57-69 (in Russian).

Kryvdik, S.G., \& Dubyna, O.V. (2006b). Geochemical peculiarities of alkaline rocks in the Dnister-Bug region of the Ukrainian Shield. Mineralogical Journal (Ukraine), 28(4), 32-42 (in Ukrainian).

Lyashkevich, Z.M., \& Zavyalova, T.V. (1977). Volcanism of the Dniper-Donetsk depression. Kyiv: Naukova Dumka, 178 (in Russian).

Melnikov, V.S., Voznyak, D.K., \& Grechanovskaya, E.E. (2000). The Azov zirconium-rare-earth deposit: mineralogical and genetic properties. Mineralogical Journal (Ukraine), 22(1), $42-61$ (in Russian).

Shcherbak N.P., Ponomarenko A.N., \& Belevtsev A.R. (2000). Geochronological boundaries of the early Precambrian of the Ukrainian Shield and their correlation with the international scale of geological time of Precambrian. Mineralogical Journal (Ukraine), 22(5/6), 5-10 (in English).

Shcherbak, N.P., Artemenko, G.V., \& Lesnaya, I.M. (2005). Geochronology of early Precambrian of the Ukrainian Shield (Archean). Kyiv: Naukova Dumka, 244 (in Russian).

Shcherbak, N.P., Artemenko, G.V., \& Lesnaya, I.M. (2008). Geochronology of early Precambrian of the Ukrainian Shield (Proterozoic). Kyiv: Naukova Dumka, 240 (in Russian).

Shramenko, I.F., Stadnik, V.A. \& Osadchy, V.K. (1992). Geochemistry of carbonatites of the Ukrainian Shield. Kyiv: Naukova Dumka, 212 pp. (in Russian).

Stern, R.J. (2007). When and how did plate tectonics begin? Theoretical and empirical considerations. Chinese Science Bulletin, 52(5), 578-591.

Strekozov, S.N., Vasilchenko, V.V., \& Gursky, D.S. (1998). Geological structure and pattern of mineralization of the Azov Deposit. Mineral resources of Ukraine, 3, 6-9 (in Russian).

Tsymbal, S.N., Shcherbakov, I.B., \& Kryvdik, S.G. (1997). Alkaline-ultrabasic rocks of the Gorodnitsky intrusion (the Northwest of the Ukrainian Shield). Mineralogical Journal (Ukraine), 19(3), 61-80 (in Russian).

Tsymbal, S.N., Geiko, Yu.V., \& Kryvdik, S.G. (2008). Bolyarkovskaya intrusion of alkaline-ultrabasic rocks (the Northwest of the Ukrainian Shield). Proceedings - International Scientific Conference "Actual problems of geology of Belarus and adjacent territories“, 9-10 December, Minsk, Belarus: NAS of Belarus, 35-40 (in Russian).

Verchogliad, V.M. (1995). Age stages of magmatism of Korosten pluton. Geochemistry and Ore Formation, 21, 34-47 (in Russian).

Zagnitko, V.N., Kryvdik, S.G., \& Legkova, G.V. (1993). Geochronology, petrology and orebearing ability of alkaline massifs of the Ukrainian Shield. In Isotopic dating of endogenous ore formations, Moscow: Nauka., 27-36 (in Russian). 